\title{
Study of the Direct Oxidation of Methane in Solid Oxide Fuel Cells
}

\author{
A.-Q. Pham
}

February 8, 2002 


\section{DISCLAIMER}

This document was prepared as an account of work sponsored by an agency of the United States Government. Neither the United States Government nor the University of California nor any of their employees, makes any warranty, express or implied, or assumes any legal liability or responsibility for the accuracy, completeness, or usefulness of any information, apparatus, product, or process disclosed, or represents that its use would not infringe privately owned rights. Reference herein to any specific commercial product, process, or service by trade name, trademark, manufacturer, or otherwise, does not necessarily constitute or imply its endorsement, recommendation, or favoring by the United States Government or the University of California. The views and opinions of authors expressed herein do not necessarily state or reflect those of the United States Government or the University of California, and shall not be used for advertising or product endorsement purposes.

This work was performed under the auspices of the U. S. Department of Energy by the University of California, Lawrence Livermore National Laboratory under Contract No. W-7405-Eng-48.

This report has been reproduced directly from the best available copy.

Available electronically at http://www.doc.gov/bridge

Available for a processing fee to U.S. Department of Energy

And its contractors in paper from

U.S. Department of Energy

Office of Scientific and Technical Information P.O. Box 62

Oak Ridge, TN 37831-0062

Telephone: (865) 576-8401

Facsimile: (865) 576-5728

E-mail: reports@adonis.osti.gov

Available for the sale to the public from

U.S. Department of Commerce

National Technical Information Service

5285 Port Royal Road

Springfield, VA 22161

Telephone: (800) 553-6847

Facsimile: (703) 605-6900

E-mail: orders@ntis.fedworld.gov

Online ordering: http://www.ntis.gov/ordering.htm

OR

Lawrence Livermore National Laboratory

Technical Information Department's Digital Library

http://www.llnl.gov/tid/Library.html 


\title{
LDRD-ER01 Final Report
}

\section{1-ERD-078}

\section{Study of the Direct Oxidation of Methane in Solid Oxide Fuel Cells}

\author{
Principal Investigator: Ai-Quoc Pham
}

\section{Introduction:}

Solid oxide fuel cells (SOFCs) are electrochemical devices that have received great interest recently because of their promise for clean and efficient power generation. Since SOFCs generate electricity directly through electrochemical processes that do not involve combustion, fuel cells are not limited by the Carnot cycle and thus, very high efficiency can be achieved. For instance, current state-of-the-art fuel cells can reach $50 \%$ efficiency while that of conventional power generation devices are generally below $30 \%$. The high efficiency is a key mean that will enable the use of fossil fuels at reduced carbon emissions.

The ideal fuel for fuel cells is hydrogen. However, hydrogen is not available directly in nature but must be made using another fossil fuel and/or energy sources. For the immediate future, except for a few niche markets, fuel cells will have to use hydrocarbons as fuel. The ideal hydrocarbon fuel would be natural gas since a natural gas infrastructure readily exists. Natural gas has indeed been used to run various fuel cells. However, natural gas cannot be used directly as a fuel for fuel cells because of its low reactivity. Natural gas must be converted to more reactive components, typically to carbon monoxide and hydrogen via the steam reforming or partial oxidation processes, before being injected in the fuel cell. The extra conversion step consumes extra energy and requires an additional reactor, thus making the overall system complex and reducing the overall efficiency. The situation is even worst if Polymer Electrolyte Membrane Fuel Cells (PEMFCs) are used since these fuel cells cannot tolerate any presence of $\mathrm{CO}$ and additional reactors are thus needed to convert $\mathrm{CO}$ to $\mathrm{H}_{2}$ and to remove residual $\mathrm{CO}$ from the gas stream.

High temperature fuel cells, especially solid oxide fuel cells (SOFCs), due to their high operating temperatures, have the potential to operate directly on natural gas. The direct operation on natural gas represents a significant simplification of the system, resulting in lower cost and higher system efficiency. To date, despite several recently published works, there is not a clear demonstration of the possibility to operate SOFCs directly on natural gas. The actual reactions that happen at the fuel cell anode are still not well understood. SOFCs.

In this one-year project, we explored the possibility of direct methane oxidation in 


\section{Accomplishments:}

Two major issues are known to hamper the direct oxidation of methane at SOFC anodes: carbon deposition due to methane pyrolysis and low reactivity. Our work was directed to address both of these issues.

\section{Carbon deposition issues:}

It is well known that all hydrocarbons tend to pyrolyze to give carbon deposition at high temperatures. Carbon deposition, which can cause plugging of the reaction sites and cracking of the cells, is thus detrimental to fuel cell anodes. We performed thermodynamic calculations to determine the stable species in typical fuel cell environment. The results indicated that coking of methane occurs at all temperatures of interest $\left(400\right.$ to $\left.800^{\circ} \mathrm{C}\right)$ if no oxygen containing species (such as water or oxygen) are present. Experimental thermogravimetric analyses (TGA) confirmed the presence of carbon for all samples that have been exposed to methane. Figure 1 shows typical TGA curves for conventional Ni/yttria-stabilized-zirconia (YSZ) anode after exposure to methane at high temperatures. When exposed to air during the TGA, these anodes are expected to gain weight due to the oxidation of nickel to nickel oxide. Experimentally, the curves indicated a weight loss, which was then attributed to the oxidation of deposited carbon to gaseous carbon dioxide. The weight change can be related to the amount of carbon deposited. The presence of steam in the gas environment was found to reduce the carbon deposition, however, a large excess of steam with a ratio of steam to carbon up to 3 was necessary to completely prevent methane coking. Such a large excess of steam is impractical in real applications and would favor the steam reforming reaction at the expense of the direct oxidation.

While the thermodynamic may favor methane coking, it is still possible to alter the kinetics of the reaction to avoid carbon deposition. In that direction, we found that the anode microstructure and materials can have significant effect on the amount of carbon deposited. Highly porous structures resulted in less carbon deposition. The use of mixed ionic electronic conducting materials such as doped-ceria as ceramic matrix of the anode also yielded much lower carbon deposition than the conventional zirconia matrix. As an example, figure 2 shows the TGA curves for ceria-based anode samples with and without pore former. These samples were initially exposed to methane/steam mixture for five hours. No weight loss was observed, indicating a much smaller carbon deposition than for Ni-YSZ anodes studied above. The sample with 15 weight $\%$ starch as pore former had extremely low carbon deposition.

\section{Anode for direct oxidation of methane:}

Using ceria as the main component for fuel cell anode, we developed single cell capable of operating directly on dry methane without the need of reforming. Figure 3 shows the performance of such a cell at $550^{\circ} \mathrm{C}$. The peak power density is $320 \mathrm{~mW} / \mathrm{cm}^{2}$. For comparison, Siemens Westinghouse fuel cell has a peak power density of less than $300 \mathrm{~mW} / \mathrm{cm}^{2}$, for an operating temperature of $1000^{\circ} \mathrm{C}$ and using reformed natural gas. Therefore, the newly developed cell enables a reduction by half of the operating temperature while being capable of operating directly on methane gas without the need of any external reforming step. The fuel cell 
efficiency for the direct oxidation cell is estimated to increase by at least $10 \%$. A US patent on the cell materials and preparation method has been filed.

\section{Reaction mechanism:}

The experiment described above indicated that our new cell could be used with methane injected directly to the anode. However, the actual reaction mechanism is still uncertain. During the oxidation of methane, steam and carbon dioxide are formed; these gases can undergo a reforming reaction with methane. The study of the actual reaction(S) is underway. The preliminary study using gas chromatography was inconclusive due to side reactions between steam and $\mathrm{CO}$ in the gas lines. Future experiments will need to use mass spectroscopy for faster collection time. However, using experimental kinetics data available in the literature, we concluded that the reforming reaction, if it happens, would be able to supply hydrogen corresponding to a current density of at most $0.18 \mathrm{~A} / \mathrm{cm}^{2}$. From the experimental data, we observed current densities up to $1.2 \mathrm{~A} / \mathrm{cm}^{2}$. Therefore, the difference can only come from the direct oxidation, indirectly proving the direct oxidation of methane in the newly developed anode.

\section{Conclusion}

We have done preliminary study of the direct oxidation of methane in SOFC anode. While the thermodynamics indicates that there is possible carbon deposition, the kinetics can be used to slow down or to suppress the deposition. This can be done either by modifying the anode material and/or improving anode porosity. We have developed single cells that are capable of operating directly on methane without reforming.

Although the present project ends after one year of development, the actual development will continue. DOE, the California Energy Commission and Solid Oxide Systems, our private industrial partner, will jointly fund the continuing effort. 


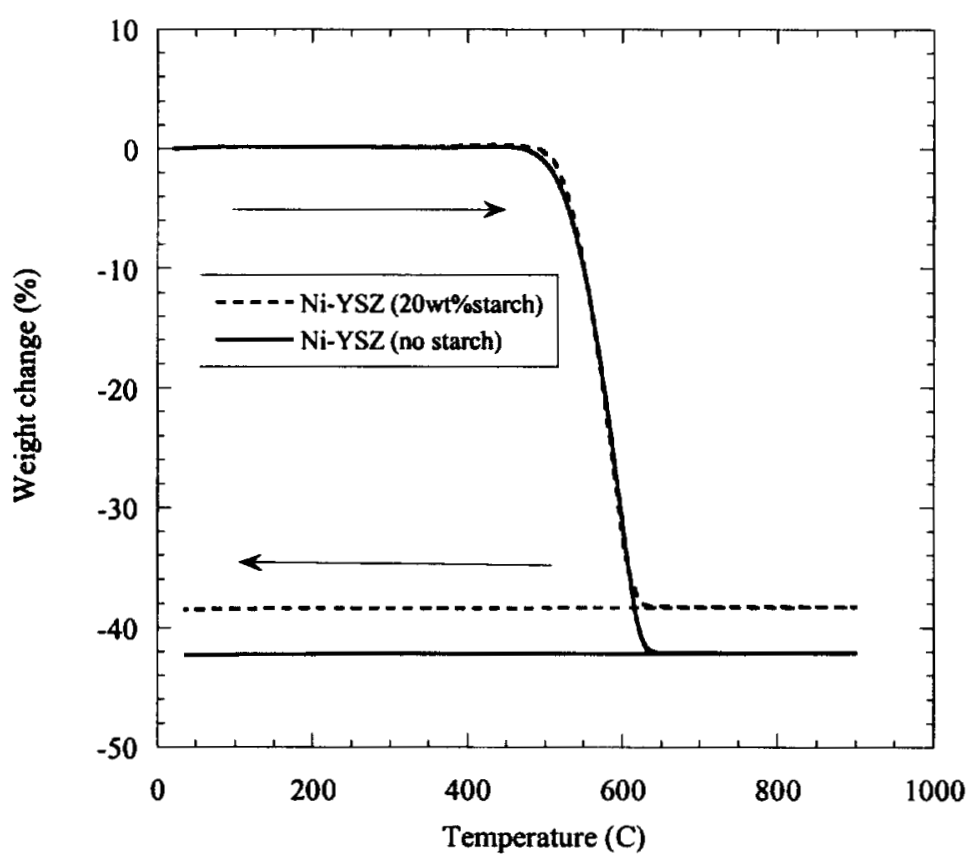

Fig.1: Thermogravimetric analysis in air of Ni-YSZ anodes after exposure to methane $\left(2.5 \% \mathrm{H}_{2} \mathrm{O}\right)$ for 5 hours at $700^{\circ} \mathrm{C}$

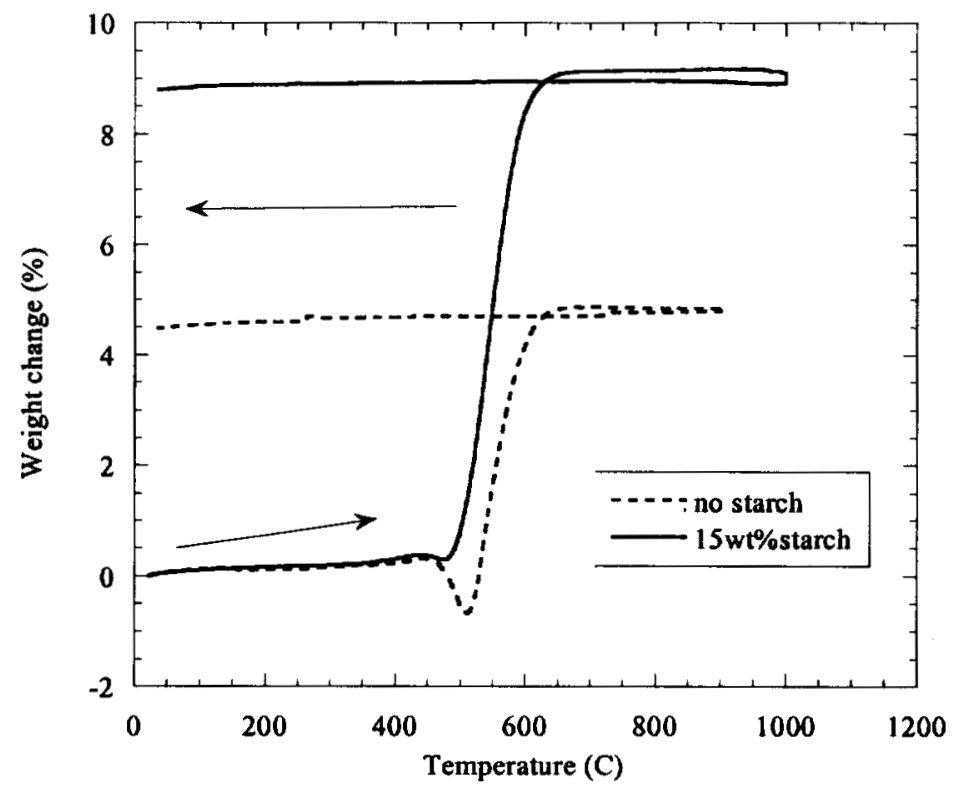

Fig.2: TGA in air of Ni-ceria anode after exposure to methane $\left(30 \% \mathrm{H}_{2} \mathrm{O}\right)$ for 5 hours at $550^{\circ} \mathrm{C}$. 


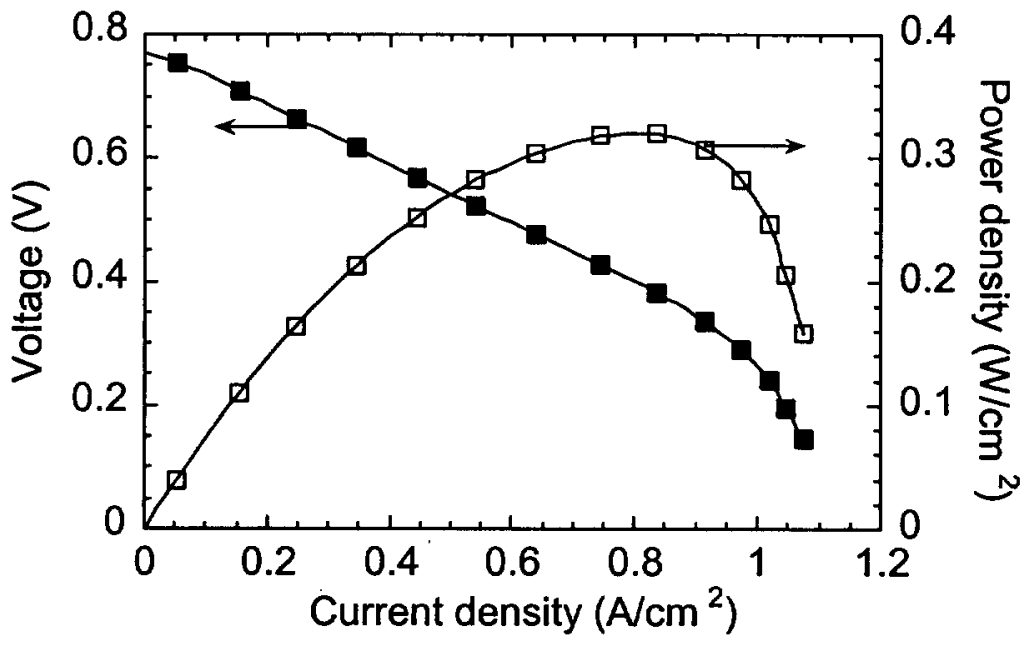

Fig.3: Performance of ceria based fuel cell operating directly on dry methane at 550C. 